\title{
Analisis Kepuasan Pengguna Sistem Informasi Administrasi Rumah Sakit (SIARS) dengan Model Delone and Mclean
}

\author{
Dony Setiawan Hendyca Putra*, Mochammad Arief Darmawan \\ Program Studi Rekam Medik Politeknik Negeri Jember, Indonesia
}

Naskah Diterima : 28 Juli 2020; Diterima Publikasi : 23 Februari 2021

DOI: 10.21456/voll1iss1pp78-85

\begin{abstract}
The Mother and Child Srikandi IBI Jember Hospital is one of the private hospitals in Jember district. Currently the Mother and Child Hospital uses the Hospital Administration Information System (HAIS) in providing services. There are several problems related to HAIS, including data that is not stored properly, the information generated by the hospital information system is still incomplete and users still have difficulty inputting data. The purpose of this study is to analyze system quality, information quality and service quality on user satisfaction. This type of research is quantitative, where there are 3 independent variables and 1 dependent variable. The results obtained are there is a moderate and unidirectional significant relationship of 0.519 between system quality and user satisfaction. There is a moderate and unidirectional significant relationship of 0.425 between information quality and user satisfaction. There is a strong and unidirectional significant relationship of 0.780 between service quality and user satisfaction. From these results it can be concluded that system quality, information quality and service quality have an influence on HAIS user satisfaction.
\end{abstract}

Keywords : Service Analysis; User Satisfaction; Delone and Mclean; Hospital Administration Information System

\begin{abstract}
Abstrak
Rumah Sakit Ibu dan Anak Srikandi IBI Jember merupakan salah satu rumah sakit swasta di kabupaten Jember. Saat ini Rumah Sakit Ibu dan Anak sudah menggunakan Sistem Informasi Administrasi Rumah Sakit (SIARS) dalam memberikan Pelayanan. Ada beberapa masalah terkait SIARS diantaranya data yang tidak tersimpan dengan baik, informasi yang dihasilkan oleh sistem informasi rumah sakit masih belum lengkap dan pengguna masih kesulitan melakukan input data. Tujuan penelitian ini adalah menganalisis kualitas sistem, kualitas informasi dan kualitas layanan terhadap kepuasan pengguna. Jenis Penelitian ini adalah kuantitatif, dimana terdapat 3 variabel bebas dan 1 variabel terikat. Hasil yang didapatkan adalah Ada hubungan signifikan yang sedang dan searah sebesar 0,519 antara kualitas sistem terhadap kepuasan pengguna. Ada hubungan signifikan yang sedang dan searah sebesar 0,425 antara kualitas informasi terhadap kepuasan pengguna. Ada hubungan signifikan yang kuat dan searah sebesar 0,780 antara kualitas layanan terhadap kepuasan pengguna. Dari hasil tersebut dapat disimpulkan bahwa kualitas sistem, kualitas informasi dan kualitas layanan memberikan pengaruh terhadap kepuasan pengguna SIARS.
\end{abstract}

Kata Kunci : Analisis Kepuasan; Kepuasan Pengguna; Delone and Mclean; Sistem Informasi Administrasi Rumah Sakit

\section{Pendahuluan}

Rumah sakit adalah institusi pelayanan kesehatan yang menyelenggarakan pelayanan kesehatan perorangan secara paripurna yang menyediakan pelayanan rawat inap, rawat jalan dan gawat darurat (Permenkes, 2010). Rumah Sakit sebagai unit kesehatan dalam kegiatannya menghasilkan data yang tidak sedikit, yang membutuhkan pengelolaan yang baik agar dapat menghasilkan informasi yang berguna. Di era modern saat ini, Rumah Sakit mengembangkan Sistem Informasi Administrasi Rumah Sakit atau yang bisa disebut SIARS yang

\footnotetext{
*) Penulis korespondensi: donssend@gmail.com
}

membantu pelayanan kesehatan teruntuk masyarakat yang ingin berobat.

RSIA Srikandi IBI Jember merupakan salah satu rumah sakit swasta di kabupaten Jember. Saat ini Rumah Sakit Ibu dan Anak sudah menggunakan Sistem Informasi Administrasi Rumah Sakit (SIARS) dalam memberikan Pelayanan. SIARS di RSIA Srikandi IBI Jember sudah berjalan sejak tahun 2011. Dengan terkaitnya SIARS, dimana peneliti akan melakukan wawancara awalan dengan petugas SIARS, petugas rekam medik, petugas di bagian pendaftaran, dan petugas pelayanan kesehatan lainnya. Dimana hasil dari wawancara tersebut didapatkan informasi bahwa semua instalasi di 
rumah sakit telah mengimplementasikan SIARS. Masalah yang dihadapi oleh pengguna Sistem Informasi Administrasi Rumah Sakit didapatkan dari hasil observasi dan wawancara, antara lain:

1) Kualitas sistem: ada beberapa data yang tidak tersimpan dengan baik.

2) Kualitas informasi: informasi yang dihasilkan oleh SIARS masih belum lengkap atau kurang lengkap.

3) Kualitas layanan: pengguna masih kesulitan melakukan input data.

4) Kepuasan pengguna: hasil survei peneliti secara subyektifitas dari pengguna Sistem Informasi Administrasi Rumah Sakit bahwa ditemukannya beberapa pengguna sistem yang kurang puas dengan Sistem Informasi Administrasi Rumah Sakit tersebut.

Berdasarkan masalah tersebut, maka menimbulkan dampak negatif. Dampak negatif yang dirasakan oleh pihak rumah sakit adalah kualitas sistem yang dihasilkan oleh SIARS masih belum maksimal. Sistem dikatakan belum maksimal jika sistem masih belum terintegrasi, kurang fleksibel dan lain sebagainya. Kualitas informasi yang dihasilkan oleh SIARS masih belum maksimal. Informasi dikatakan belum maksimal jika informasi kurang cepat, kurang lengkap, kurang relevan, kurang akurat dan lain sebagainya. Kualitas layanan yang dihasilkan oleh SIARS masih belum maksimal. Kualitas layanan dikatakan belum maksimal jika sistem sulit digunakan untuk proses pelayanan. Kepuasan pengguna masih kurang puas.

Oleh karena itu, tujuan penelitian ini untuk menganalisis kualitas sistem, kualitas informasi, kualitas layanan, terhadap kepuasan pengguna Sistem Informasi Administrasi Rumah Sakit.

\section{Kerangka Teori}

Model kesuksesan sistem informasi Delone and Mclean, diperkenalkan pertama kali oleh William $\mathrm{H}$. Delone dan Ephraim R. Mclean. Penelitian yang telah dilakukan pertama kali tahun 1992 dalam mengidentifikasi faktor yang menyebabkan kesuksesan sistem informasi. Model Delone and Mclean adalah sebuah model yang digunakan untuk mengukur kesuksesan dari sistem informasi. Model ini dikenal sebagai model yang sederhana tetapi dianggap cukup valid oleh para peneliti. Akhirnya dengan perubahan peran dari sistem informasi selama 10 tahun sejak dikenalkan model Delone and Mclean pertama kali, maka Delone and Mclean pada tahun 2003 memperbaiki dan memutakhirkan modelnya. Model kesuksesan sistem informasi Delone and Mclean (2003) yaitu: judul gambar ditempatkan di bawah gambar dengan posisi rata tengah. Judul tabel berada di atas tabel dengan posisi rata kanan kiri (justify). Hindari penempatan gambar dan tabel sebelum disebutkan di teks.

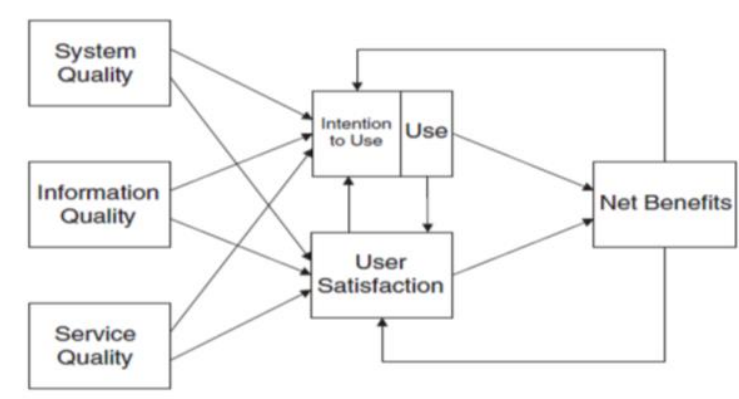

Gambar 1. Model Delone and Mclean (2003)

Setiap item-item tersebut telah dikelompokkan sebagai berikut:

1. Kualitas Sistem (System quality)

Menurut Delone and Mclean (2003) bahwa system quality adalah kualitas dari kombinasi hardware dan software dalam sistem informasi. Berfokus pada performa sistem yang merujuk pada seberapa baik kemampuan hardware, software, kebijakan, prosedur dari sistem informasi dapat menyediakan kebutuhan pengguna. Dalam penelitian ini kualitas sistem yang dimaksud adalah keakurasian dan efisiensi dari Sistem Informasi dalam menghasilkan informasi.

Indikator pengukuran kualitas sistem yang akan digunakan dalam penelitian ini yaitu :

a. Mudah digunakan (Ease of Use)

Suatu sistem informasi dapat dikatakan berkualitas jika sistem tersebut dirancang untuk memenuhi kepuasan pengguna melalui kemudahan dalam menggunakan sistem informasi tersebut. Kemudahan penggunaan dalam konteks ini bukan saja kemudahan untuk mempelajari dan menggunakan suatu sistem tetapi juga mengacu pada kemudahan dalam melakukan suatu pekerjaan atau tugas dimana pemakaian suatu sistem akan semakin memudahkan seseorang dalam bekerja dibanding mengerjakan secara manual.

b. Integrasi (Integration)

Apabila sistem-sistem yang ada dalam organisasi telah terintegrasi tentunya akan sangat mempermudah karyawan saat bekerja. Integrasi data juga ditandai dengan semua data dari tiap bagian dapat digabungkan dengan data dari bagian lain.

c. Fleksibilitas (Flexibility)

Fleksibilitas suatu sistem informasi menunjukkan bahwa sistem informasi yang diterapkan tersebut memiliki kualitas yang baik. Fleksibilitas yang dimaksud adalah kemampuan sistem informasi dalam melakukan perubahan-perubahan yang berkaitan dengan kebutuhan pengguna. Pengguna akan merasa lebih puas menggunakan suatu sistem informasi jika sistem tersebut fleksibel dalam memenuhi kebutuhan pengguna.

d. Kecepatan Akses (Response Time)

Kecepatan akses merupakan salah satu indikator kualitas sistem informasi. Jika akses sistem informasi 
memiliki kecepatan yang optimal maka layak dikatakan bahwa sistem informasi yang diterapkan memiliki kualitas yang baik. Kecepatan akses akan meningkatkan kepuasan pengguna dalam menggunakan sistem informasi.

e. Keamanan (Security)

Suatu sistem informasi dapat dikatakan baik jika keamanan sistem tersebut dapat diandalkan. Keamanan sistem ini dapat dilihat melalui data pengguna yang aman disimpan oleh suatu sistem informasi. Data pengguna ini harus terjaga kerahasiaanya dengan cara data disimpan oleh sistem informasi sehingga pihak lain tidak dapat mengakses data pengguna secara bebas. Jika data pengguna dapat disimpan secara aman maka akan memperkecil kesempatan pihak lain untuk menyalahgunakan data pengguna sistem informasi tersebut.

f. Keandalan Sistem (System Reliability)

Sistem informai yang berkualitas adalah sistem informasi yang dapat diandalkan. Jika sistem tersebut dapat diandalkan maka sistem informasi tersebut layak digunakan. Keandalan sistem informasi dalam konteks ini adalah ketahanan sistem informasi dari kerusakan dan kesalahan. Keandalan sistem informasi ini juga dapat dilihat dari sistem informasi yang melayani kebutuhan pengguna tanpa adanya masalah yang dapat mengganggu kenyamanan pengguna dalam menggunakan sistem informasi.

2. Kualitas Informasi (Information quality)

Menurut Delone and Mclean (2003) bahwa kualitas informasi merupakan output dari penggunan sistem informasi oleh pengguna (user). Variabel ini menggambarkan kualitas informasi yang dipersepsikan oleh pengguna yang diukur dengan keakuratan informasi (accuracy), relevan (relevance), kelengkapan informasi (completeness), ketepatan waktu (timeliness), dan penyajian informasi (format).

Indikator pengukuran kualitas informasi yang akan digunakan dalam penelitian ini yaitu :

a. Kelengkapan (Completeness)

Suatu informasi yang dihasilkan oleh sistem informasi dapat dikatakan berkualitas jika informasi yang dihasilkan lengkap. Informasi yang lengkap ini sangat dibutuhkan oleh pengguna dalam pengambilan keputusan. Informasi yang lengkap ini mencakup seluruh informasi yang dibutuhkan oleh pengguna dalam menggunakan sistem informasi tersebut. Jika informasi yang tersedia dalam sistem informasi lengkap maka akan memuaskan pengguna. Pengguna mungkin akan menggunakan sistem informasi tersebut secara berkala setelah merasa puas terhadap sistem informasi tersebut.

b. Relevan (Relevance)

Kualitas informasi suatu sistem informasi dikatakan baik jika relevan terhadap kebutuhan pengguna atau dengan kata lain informasi tersebut mempunyai manfaat untuk penggunanya. Relevansi informasi untuk tiap-tiap pengguna satu dengan yang lainnya berbeda sesuai dengan kebutuhan masing-masing.

c. Akurat (Accurate)

Informasi yang dihasilkan oleh sistem informasi harus akurat karena sangat berperan bagi pengambilan keputusan penggunanya. Informasi yang akurat berarti harus bebas dari kesalahankesalahan dan tidak bias atau menyesatkan. Akurat juga berarti informasi harus jelas mencerminkan maksud informasi yang disediakan oleh sistem informasi. Informasi harus akurat karena dari sumber informasi sampai ke penerima informasi kemungkinan banyak terjadi gangguan (noise) yang dapat merubah atau merusak informasi tersebut.

d. Ketepatan waktu (Timeliness)

Informasi yang datang pada penerima tidak boleh terlambat, informasi yang sudah usang tidak akan mempunyai nilai lagi, karena informasi merupakan landasan didalam pengambilan keputusan. Jika pengambilan keputusan terlambat, maka dapat berakibat fatal untuk organisasi sebagai pengguna sistem informasi tersebut. Oleh karena itu dapat dikatakan bahwa kualitas informasi yang dihasilkan sistem informasi baik jika informasi yang dihasilkan tepat waktu.

e. Penyajian Informasi (Format)

Format sistem informasi perpustakaan yang memudahkan pengguna untuk memahami informasi yang disediakan oleh sistem informasi mencerminkan kualitas informasi yang baik. Jika penyajian informasi disajikan dalam bentuk yang tepat maka informasi yang dihasilkan dianggap berkualitas sehingga memudahkan pengguna untuk memahami informasi yang dihasilkan oleh suatu sistem informasi. Format informasi mengacu kepada bagaimana informasi dipresentasikan kepada pengguna.

3. Kualitas layanan (Service quality)

Menurut Delone and Mclean (2003) bahwa kualitas layanan sistem informasi merupakan pelayanan yang diperoleh pengguna dari pengembang sistem informasi, layanan dapat berupa update sistem informasi dan respon dari pengembang jika sistem informasi mengalami masalah.

Beberapa indikator pada kualitas layanan yang akan digunakan dalam penelitian ini yaitu :

a. Wujud Fisik (Tangible)

Suatu bentuk penampilan fisik, peralatan personal, media komunikasi, dan hal-hal lainnya yang bersifat fisik dan suatu kemampuan organisasi dalam menunjukkan eksitensi kepada pihak eksternal.

b. Kehandalan (Reliability)

Suatu kemampuan untuk memberikan perhatian jasa yang dijanjikan dengan akurat dan terpercaya serta kinerja harus sesuai dengan harapan pelanggan dengan adanya ketepatan waktu, pelayanan yang sama untuk semua pelanggan tanpa adanya kesalahan, sikap yang penuh simpatik dan dengan akurasi yang tinggi. 


\section{c. Ketanggapan (Responsive)}

Suatu respon pemberi jasa dalam membantu public dan memberikan pelayanan yang cepat dan tanggap dengan suatu kemauan untuk membantu dan memberikan pelayanan yang tepat kepada pelanggan.

d. Jaminan (Ansurance)

Jaminan, dimana SIARS memberikan kemudahan pengguna dalam melakukan pekerjaannya dengan mempercepat pelayanannya.

e. Empati (Empathy)

Empati adalah sikap kepedulian pihak pengembang sistem informasi kepada pengguna ketika pengguna menanyakan hal-hal yang berkaitan dengan sistem informasi yang dibangun.

Dari uraian diatas, penelitian ini mengambil hipotesis penelitian yaitu:

1. Ha: Ada hubungan kualitas sistem terhadap kepuasan pengguna SIARS di RSIA Srikandi IBI Jember.

2. Ha: Ada hubungan kualitas informasi terhadap kepuasan pengguna SIARS di RSIA Srikandi IBI Jember.

Ha: Ada hubungan kualitas layanan terhadap kepuasan pengguna SIARS di RSIA Srikandi IBI Jember.

\section{Metode}

Penelitian ini menggunakan penelitian kuantitatif. Penelitian ini menggunakan metode Delone and Mclean (2003) yang terdiri dari 7 variabel, yaitu : kualitas sistem, kualitas informasi, kualitas layanan, intensitas penggunaan, penggunaan sistem, kepuasan pengguna dan net benefits (Delone and Mclean, 2003).

Subjek penelitian yang digunakan dalam penelitian ini adalah populasi petugas yang berkaitan SIARS dengan memiliki username dan password yakni sebanyak 70 orang dan sampel petugas yang berkaitan SIARS dengan memiliki username dan password yakni sebanyak 60 orang yang didapat dari rumus slovin. Populasi adalah wilayah generalisasi yang terdiri atas obyek/subyek yang mempunyai kualitas dan karakteristik tertentu yang ditetapkan oleh peneliti untuk dipelajari dan kemudian ditarik kesimpulannya (Putra dan Prasetyo, 2015). Sedangkan Sampel adalah sebagian yang diambil dari keseluruhan objek yang diteliti dan dianggap mewakili seluruh populasi (Notoatmodjo, 2005).

Teknik pengambilan sampel dalam penelitian ini menggunakan jenis probability sampling yaitu teknik proportionate stratified random sampling dengan menggunakan rumus Slovin. Probability sampling adalah teknik pengambilan sampel yang memberikan peluang yang sama bagi setiap unsur (anggota) populasi untuk dipilih menjadi anggota sampel (Sugiyono, 2010). Proportionate stratified random sampling, digunakan karena populasi mempunyai anggota/unsur yang tidak homogen dan berstrata secara proporsional (Sugiyono, 2012).
Metode pengumpulan data dengan cara membuat kuisioner yang disesuaikan dengan beberapa variabel dari metode Delone and Mclean (2003) dan melakukan uji coba kuisioner untuk mendapat hasil yang valid dan reliabel, kemudian membagikan kuisioner yang sudah valid dan reliabel kepada responden penelitian untuk mengisi kuisioner tersebut berdasarkan penilaian masing-masing individu.

Menurut Sugiyono (2012) bahwa untuk menilai variabel independen dan variabel dependen, maka analisis yang digunakan berdasarkan rata-rata (mean) dari masing-masing variabel. Nilai rata-rata (mean) ini diperoleh dengan menjumlahkan data keseluruhan dalam setiap variabel, kemudian dibagi dengan jumlah responden. Untuk rumus rata-rata digunakan sebagai berikut :

$$
\mathrm{Me}=\frac{\sum z}{n}
$$

Keterangan

$\mathrm{Me}=$ Rata-rata

$\sum \mathrm{z}=$ Jumlah Nilai X/Y ke-i sampai ke-n

$\mathrm{n}=$ Jumlah responden yang akan dirata-rata

Setelah diperoleh rata-rata dari masing-masing variabel kemudian dibandingkan dengan kriteria yang peneliti tentukan berdasarkan nilai terendah dan nilai tertinggi dari hasil kuesioner. Nilai terendah dan nilai tertinggi itu masing-masing peneliti ambil dari banyaknya pertanyaan dalam kuesioner dikalikan dengan nilai terendah (1) dan nilai tertinggi (4) yang telah ditetapkan.

Berdasarkan nilai tertinggi dan terendah tersebut, maka dapat ditentukan rentang interval yaitu nilai tertiggi dikurangi nilai terendah, sedangkan menghitung panjang kelas dengan cara rentang interval dibagi dengan jumlah kelas.

Untuk variabel independen kualitas sistem dengan 8 pernyataan, nilai tertinggi dikalikan dengan 4 dan nilai terendah dikalikan dengan 1 , sehingga :

Nilai tertinggi $8 \times 4=32$

Nilai terendah $8 \times 1=8$

Lalu kelas interval sebesar $((32-8) / 4)=6$ maka peneliti menentukan kriteria sebagai berikut:

Tabel 1. Interval Variabel Kualitas Sistem

\begin{tabular}{cc}
\hline Nilai & Kriteria \\
\hline $8-14$ & Sangat Tidak Baik \\
$14,1-20$ & Tidak Baik \\
$20,1-26$ & Baik \\
$26,1-32$ & Sangat Baik \\
\hline
\end{tabular}

Untuk variabel independen kualitas informasi dengan 6 pertanyaan, nilai tertinggi dikalikan dengan 4 dan nilai terendah dikalikan dengan 1 , sehingga :

Nilai tertinggi $6 \times 4=24$

Nilai terendah $6 \times 1=6$

Lalu kelas interval sebesar $((24-6) / 4)=6$ maka peneliti menentukan kriteria sebagai berikut: 
Tabel 2. Interval Variabel Kualitas Informasi

\begin{tabular}{cc}
\hline Nilai & Kriteria \\
\hline $6-10,5$ & Sangat Tidak Baik \\
$10,6-15$ & Tidak Baik \\
$15,1-19,5$ & Baik \\
$19,6-24$ & Sangat Baik \\
\hline
\end{tabular}

Untuk variabel independen kualitas layanan dengan 5 pertanyaan, nilai tertinggi dikalikan dengan 4 dan nilai terendah dikalikan dengan 1 , sehingga :

Nilai tertinggi $5 \times 4=20$

Nilai terendah $5 \times 1=5$

Lalu kelas interval sebesar $((20-5) / 4)=3,75$ maka peneliti menentukan kriteria sebagai berikut:

Tabel 3. Interval Variabel Kualitas Layanan

\begin{tabular}{cc}
\hline Nilai & Kriteria \\
\hline $5-8,75$ & Sangat Tidak Baik \\
$8,76-12,5$ & Tidak Baik \\
$12,51-16,25$ & Baik \\
$16,26-20$ & Sangat Baik \\
\hline
\end{tabular}

Untuk variabel dependen kepuasan pengguna dengan 5 pertanyaan, nilai tertinggi dikalikan dengan 4 dan nilai terendah dikalikan dengan 1 , sehingga :

Nilai tertinggi $5 \times 4=20$

Nilai terendah $5 \times 1=5$

Lalu kelas interval sebesar $((20-5) / 4)=3,75$ maka peneliti menentukan kriteria sebagai berikut:

Tabel 4. Interval Variabel Kepuasan Pengguna

\begin{tabular}{cc}
\hline Nilai & Kriteria \\
\hline $5-8,75$ & Sangat Tidak Baik \\
$8,76-12,5$ & Tidak Baik \\
$12,51-16,25$ & Baik \\
$16,26-20$ & Sangat Baik \\
\hline
\end{tabular}

\section{Hasil dan Pembahasan}

4.1. Mengidentifikasi kualitas sistem, kualitas informasi, kualitas layanan dan kepuasan pengguna

a. Identifikasi Variabel Kualitas Sistem

Identifikasi variable kualitas sistem dapat dilihat pada Tabel 5 dibawah ini.

Tabel 5. Identifikasi Variabel Kualitas Sistem

\begin{tabular}{|c|c|c|c|c|c|c|c|c|c|c|c|}
\hline $\begin{array}{l}\mathrm{N} \\
\mathrm{o}\end{array}$ & $\mathrm{K}$ & 1 & 2 & 3 & 4 & 5 & 6 & 7 & 8 & $\mathrm{~N}$ & $\mathrm{NxS}$ \\
\hline 1 & SB & 16 & 4 & 8 & 4 & 7 & 8 & 10 & 7 & 64 & 256 \\
\hline 2 & B & 44 & 45 & 43 & 44 & 29 & 39 & 42 & $\begin{array}{l}3 \\
2\end{array}$ & 318 & 954 \\
\hline 3 & TB & 0 & 11 & 9 & 12 & 24 & 13 & 8 & $\begin{array}{l}1 \\
9\end{array}$ & 96 & 192 \\
\hline 4 & STB & 0 & 0 & 0 & 0 & 0 & 0 & 0 & 2 & 2 & 2 \\
\hline \multicolumn{11}{|c|}{ Mean } & 23.4 \\
\hline
\end{tabular}

Dari Tabel 1, menunjukkan jumlah skor yang ada di variabel kualitas sistem, yaitu kriteria sangat baik berjumlah sebesar 256, kriteria baik berjumlah sebesar 954, kriteria tidak baik berjumlah sebesar 192 dan kriteria Sangat tidak baik berjumlah sebesar
2. Dari hasil data yang tertera diatas, peneliti dapat mengetahui bahwa mean sebesar 23,4. Dengan mean sebesar 23,4 dapat diambil keputusan bahwa kualitas sistem masuk dalam kategori baik dengan interval 20,1-26. Meskipun dengan nilai rata-rata yang masuk dalam kategori baik, masih ada responden yang memilih tidak baik bahkan ada reponden yang juga memilih sangat tidak baik. Hal tersebut didukung dengan penemuan peneliti terkait kendala registrasi data pasien yang masih belum tersimpan dengan baik yang mengakibatkan terganggunya pelayanan kesehatan.

b. Identifikasi Variabel Kualitas Informasi

Identifikasi Variabel Kualitas Informasi dapat dilihat pada Tabel 6.

\begin{tabular}{cccccccccc}
\multicolumn{10}{l}{ Tabel 6. Identifikasi Variabel Kualitas Informasi } \\
\hline No. & K & 1 & 2 & 3 & 4 & 5 & 6 & N & NxSkor \\
\hline 1 & SB & 3 & 6 & 5 & 11 & 5 & 5 & 35 & 140 \\
2 & B & 37 & 38 & 51 & 45 & 49 & 39 & 259 & 777 \\
3 & TB & 20 & 16 & 4 & 4 & 6 & 13 & 63 & 126 \\
4 & STB & 0 & 0 & 0 & 0 & 0 & 3 & 3 & 3 \\
& \multicolumn{10}{c}{ Mean } & & & & & 17.43 \\
\hline
\end{tabular}

Dari Tabel 2, bahwa data tersebut menunjukkan jumlah skor yang ada di variabel kualitas informasi, yaitu kriteria sangat baik berjumlah sebesar 140, kriteria baik berjumlah sebesar 777, Kriteria tidak baik berjumlah sebesar 126 dan kriteria sangat tidak baik berjumlah sebesar 3. Dari hasil data yang tertera diatas, peneliti dapat mengetahui bahwa mean sebesar 17,43. Dengan mean sebesar 17,43 dapat diambil keputusan bahwa kualitas informasi masuk dalam kategori baik dengan interval 15,1-19,5. Meskipun dengan nilai rata-rata yang masuk dalam kategori baik, bahwa masih ada responden yang memilih tidak baik dan bahkan ada yang memilih sangat tidak baik. Hal tersebut didukung dengan penemuan peneliti di unit rekam medis pada SIARS bahwa terdapat hasil informasi diagnosa pasien yang tidak sesuai dan tidak relevan dengan diagnosa yang diisi sebelumnya.

c. Identifikasi Variabel Kualitas Layanan

Identifikasi variable kualitas layanan dapat dilihat pada Tabel 7 dibawah ini.

Tabel 7. Identifikasi Variabel Kualitas Layanan

\begin{tabular}{|c|c|c|c|c|c|c|c|c|}
\hline No. & $\mathrm{K}$ & 1 & 2 & 3 & 4 & 5 & $\mathrm{~N}$ & NxSkor \\
\hline 1 & SB & 2 & 13 & 11 & 12 & 16 & 54 & 216 \\
\hline 2 & B & 42 & 41 & 43 & 39 & 42 & 207 & 621 \\
\hline 3 & $\mathrm{~TB}$ & 16 & 5 & 6 & 9 & 2 & 38 & 76 \\
\hline 4 & STB & 0 & 1 & 0 & 0 & 0 & 1 & 1 \\
\hline \multicolumn{8}{|c|}{ Mean } & 15.23 \\
\hline
\end{tabular}

Dari Tabel 7, bahwa data tersebut menunjukkan jumlah skor yang ada di variabel kualitas layanan, 
yaitu kriteria sangat baik berjumlah sebesar 216, kriteria baik berjumlah sebesar 621, kriteria tidak baik berjumlah sebesar 76 dan kriteria sangat tidak baik berjumlah sebesar 1. Dari hasil data yang tertera diatas, peneliti dapat mengetahui bahwa mean sebesar 15,23. Dengan mean sebesar 15,23 dapat diambil keputusan bahwa kualitas sistem masuk dalam kategori baik dengan interval 12,51-16,25. Meskipun dengan nilai rata-rata yang masuk dalam kategori baik dan bahkan ada yang memilih sangat tidak baik. Hal tersebut didukung dengan penemuan peneliti bahwa terdapat beberapa petugas yang baru mengalami kesulitan saat mengoperasikan SIARS karena butuh adaptasi yang lebih lama untuk menggunakan sistem tersebut.

d. Identifikasi Variabel Kepuasan Pengguna

Identifikasi variable kepuasan pengguna dapat dilihat pada Tabel 8 dibawah ini.

Tabel 8. Identifikasi Variabel Kepuasan Pengguna

\begin{tabular}{ccccccccc}
\hline No. & K & $\mathbf{1}$ & $\mathbf{2}$ & $\mathbf{3}$ & $\mathbf{4}$ & $\mathbf{5}$ & $\mathbf{N}$ & NxSkor \\
\hline 1 & SB & 18 & 6 & 18 & 17 & 8 & 67 & 268 \\
2 & B & 42 & 53 & 41 & 41 & 44 & 221 & 663 \\
3 & TB & 0 & 1 & 1 & 2 & 8 & 12 & 24 \\
4 & STB & 0 & 0 & 0 & 0 & 0 & 0 & 0 \\
& & & & Mean & & & & 15.92 \\
\hline
\end{tabular}

Dari Tabel 8, bahwa data tersebut menunjukkan jumlah skor yang ada di variabel kepuasan pengguna, yaitu kriteria sangat baik berjumlah sebesar 268, kriteria baik berjumlah sebesar 663, kriteria tidak baik berjumlah sebesar 24 dan sangat tidak baik berjumlah sebesar 0. Dari hasil data yang tertera diatas, peneliti dapat mengetahui bahwa mean sebesar 15,92. Dengan mean sebesar 15,92 dapat diambil keputusan bahwa kepuasan pengguna masuk dalam kategori baik dengan interval 12,51-16,25. Meskipun dengan nilai rata-rata yang masuk dalam kategori baik, bahwa masih ada responden yang memilih kategori tidak baik. Hal tersebut didukung dengan penemuan peneliti terkait kendala SIARS yang belum terintegrasi dengan aplikasi BPJS, oleh sebab itu berdampak kepada kepuasan pengguna. .

\subsection{Menganalisis kualitas sistem terhadap kepuasan pengguna SIARS di RSIA Srikandi IBI Jember}

Kualitas sistem adalah kualitas dari kombinasi hardware dan software dalam sistem informasi dan kepuasan pengguna merupakan respon dan umpan balik yang dimunculkan pengguna setelah memakai sistem informasi (Delone and Mclean, 2003).

Hasil uji spearman ank kualitas system terhadap kepuasan pengguna dapat dilihat pada Tabel 9 berikut ini.
Tabel 9. Hasil Uji Spearman Rank Kualitas Sistem Terhadap Kepuasan Pengguna

\begin{tabular}{|c|c|c|c|c|}
\hline \multicolumn{5}{|c|}{ Correlations } \\
\hline & & & $\begin{array}{l}\text { Kualitas } \\
\text { Sistem }\end{array}$ & $\begin{array}{l}\text { Kepuasan } \\
\text { Pengguna }\end{array}$ \\
\hline \multirow{8}{*}{$\begin{array}{l}\text { Spearma } \\
\text { n's rho }\end{array}$} & \multirow{4}{*}{$\begin{array}{l}\text { Kualitas } \\
\text { Sistem }\end{array}$} & Correlation & 1.000 & $.519^{* *}$ \\
\hline & & Coefficient & & \\
\hline & & Sig. (2-tailed) & & .000 \\
\hline & & $\mathrm{N}$ & 60 & 60 \\
\hline & \multirow{4}{*}{$\begin{array}{l}\text { Kepuasan } \\
\text { Pengguna }\end{array}$} & Correlation & $.519^{* * *}$ & 1.000 \\
\hline & & Coefficient & & \\
\hline & & Sig. (2-tailed) & .000 & \\
\hline & & $\mathrm{N}$ & 60 & 60 \\
\hline
\end{tabular}

Dari Tabel 9, bahwa hasil perhitungan yang dilakukan oleh peneliti dengan jumlah N (Jumlah Responden) adalah 60, pertama diketahui hasil nilai signifikansi atau Sig. (2-tailed) sebesar 0,000, karena nilai Sig. (2-tailed) $0,000<$ lebih kecil dari 0.05, maka artinya ada hubungan yang signifikansi (berarti) antara variabel kualitas sistem terhadap kepuasan pengguna. Kedua diperoleh angka correlation coefficient sebesar 0,519. Artinya tingkat kekuatan hubungan (korelasi) antara variabel kualitas sistem terhadap kepuasan pengguna adalah sebesar 0,519 atau sedang. Ketiga angka correlation coefficient pada hasil diatas bernilai positif, yaitu sebesar 0,519. Sehingga hubungan kedua variabel tersebut bersifat searah (jenis hubungan searah), dengan demikian dapat diartikan bahwa kualitas sistem ditingkatkan maka kepuasan pengguna juga akan meningkat.

Oleh sebab itu, hasil penelitian ini juga sesuai dengan penelitian Livari (2005) dan Putra dan Siswanto (2016), bahwa sebuah sistem informasi yang dapat memenuhi kebutuhan pengguna akan meningkatkan kepuasan pengguna. Hal tersebut diwujudkan dengan kecenderungan peningkatan dalam kualitas sistem informasi tersebut.

Dengan demikian maka, dapat disimpulkan bahwa Ho ditolak dan $\mathrm{Ha}$ diterima. Artinya ada hubungan signifikan yang sedang dan searah antara kualitas sistem terhadap kepuasan pengguna sistem informasi manajemen rumah sakit di RSIA Srikandi Jember.

\subsection{Menganalisis kualitas informasi terhadap kepuasan pengguna SIARS di RSIA Srikandi IBI Jember}

Kualitas informasi merupakan output dari penggunan sistem informasi oleh pengguna (user) dan kepuasan pengguna merupakan respon dan umpan balik yang dimunculkan pengguna setelah memakai sistem informasi (Delone and Mclean, 2003). 
Tabel 10. Hasil uji spearman rank kualitas informasi terhadap kepuasan pengguna

\begin{tabular}{|c|c|c|c|c|}
\hline \multicolumn{5}{|c|}{ Correlations } \\
\hline & & & $\begin{array}{l}\text { Kualitas } \\
\text { Informasi }\end{array}$ & $\begin{array}{l}\text { Kepuasan } \\
\text { Penoguna }\end{array}$ \\
\hline \multirow{8}{*}{$\begin{array}{l}\text { Spearm } \\
\text { an's } \\
\text { rho }\end{array}$} & \multirow{4}{*}{$\begin{array}{l}\text { Kualitas } \\
\text { Informasi }\end{array}$} & Correlation & 1.000 & $.425^{* *}$ \\
\hline & & Coefficient & & \\
\hline & & Sig. (2-tailed) & & .001 \\
\hline & & $\mathrm{N}$ & 60 & 60 \\
\hline & \multirow{4}{*}{$\begin{array}{l}\text { Kepuasan } \\
\text { Pengguna }\end{array}$} & Correlation & $.425^{* *}$ & 1.000 \\
\hline & & Coefficient & & \\
\hline & & Sig. (2-tailed) & .001 & . \\
\hline & & $\mathrm{N}$ & 60 & 60 \\
\hline
\end{tabular}

Dari Tabel 10, bahwa hasil perhitungan yang dilakukan oleh peneliti dengan jumlah N (Jumlah Responden) adalah 60, pertama diketahui hasil nilai signifikansi atau Sig. (2-tailed) sebesar 0,001, karena nilai Sig. (2-tailed) $0,001<$ lebih kecil dari 0.05 , maka artinya ada hubungan yang signifikansi (berarti) antara variabel kualitas informasi terhadap kepuasan pengguna. Kedua diperoleh angka correlation coefficient sebesar 0,425. Artinya tingkat kekuatan hubungan (korelasi) antara variabel kualitas informasi terhadap kepuasan pengguna adalah sebesar 0,425 atau sedang. Ketiga angka correlation coefficient pada hasil diatas bernilai positif, yaitu sebesar 0,425. Sehingga hubungan kedua variabel tersebut bersifat searah (jenis hubungan searah), dengan demikian dapat diartikan bahwa kualitas informasi ditingkatkan maka kepuasan pengguna juga akan meningkat.

Oleh karena itu, hasil penelitian ini juga sejalan dengan penelitian yang dilakukan oleh Budiastuti (2015) dan Wahyuni (2011), bahwa kualitas informasi dari sistem informasi berhubungan positif dengan kepuasan pengguna. Hasil penelitian ini juga menunjukkan bahwa kualitas informasi yang dihasilkan dari sistem informasi masih dalam kategori sedang sehingga pengguna sistem bisa dinyatakan puas dalam menggunakan SIARS. Hal ini diperkuat oleh penelitian, Wahyuni (2011) bahwa berdasarkan persepsi pengguna, semakin tinggi kualitas informasi yang dihasilkan dari sistem maka semakin meningkatkan kepuasan pengguna.

Dengan demikian maka, peneliti dapat menyimpulkan bahwa Ho ditolak dan Ha diterima. Artinya ada hubungan signifikan yang sedang dan searah antara kualitas informasi terhadap kepuasan pengguna sistem informasi manajemen rumah sakit di RSIA Srikandi Jember.

\subsection{Menganalisis kualitas layanan terhadap kepuasan pengguna SIARS di RSIA Srikandi IBI Jember}

Kualitas layanan sistem informasi merupakan pelayanan yang diperoleh pengguna dari pengembang sistem informasi, layanan dapat berupa update sistem informasi dan respon dari pengembang jika sistem informasi mengalami masalah dan kepuasan pengguna merupakan respon dan umpan balik yang dimunculkan pengguna setelah memakai sistem informasi (Delone and Mclean, 2003).

Tabel 11. Hasil uji spearman rank kualitas layanan terhadap kepuasan pengguna

\begin{tabular}{|c|c|c|c|c|}
\hline \multicolumn{5}{|c|}{ Correlations } \\
\hline & & & Kualitas & $\begin{array}{l}\text { Kepuasan } \\
\text { Pengouna }\end{array}$ \\
\hline \multirow[t]{6}{*}{$\begin{array}{l}\text { Spearm } \\
\text { an's rho }\end{array}$} & $\begin{array}{l}\text { Kualitas } \\
\text { Layanan }\end{array}$ & $\begin{array}{l}\text { Correlation } \\
\text { Coefficient }\end{array}$ & 1.000 & $.780^{* *}$ \\
\hline & & Sig. (2-tailed) & & .000 \\
\hline & & $\mathrm{N}$ & 60 & 60 \\
\hline & Kepuasan & Correlation & $.780^{* *}$ & 1.000 \\
\hline & & Sig. (2-tailed) & .000 & \\
\hline & & $\mathrm{N}$ & 60 & 60 \\
\hline
\end{tabular}

**. Correlation is significant at the 0.01 level (2-tailed).

Dari Tabel 11, bahwa hasil perhitungan yang dilakukan oleh peneliti dengan jumlah N (Jumlah Responden) adalah 60, pertama diketahui hasil nilai signifikansi atau Sig. (2-tailed) sebesar 0,000, karena nilai Sig. (2-tailed) $0,000<$ lebih kecil dari 0.05, maka artinya ada hubungan yang signifikansi (berarti) antara variabel kualitas layanan terhadap kepuasan pengguna. Kedua diperoleh angka correlation coefficient sebesar 0,780. Artinya tingkat kekuatan hubungan (korelasi) antara variabel kualitas layanan terhadap kepuasan pengguna adalah sebesar 0,780 atau kuat. Ketiga angka correlation coefficient pada hasil diatas bernilai positif, yaitu sebesar 0,780. Sehingga hubungan kedua variabel tersebut bersifat searah (jenis hubungan searah), dengan demikian dapat diartikan bahwa kualitas layanan ditingkatkan maka kepuasan pengguna juga akan meningkat.

Oleh karena itu, hasil penelitian ini juga sejalan dengan penelitian yang dilakukan oleh Budiastuti (2015) dan Salim (2014) bahwa terdapat hubungan yang positif antara kualitas layanan terhadap kepuasan pengguna. Menurut Petter (2008) menyatakan bahwa kualitas layanan yang dihasilkan oleh suatu sistem informasi akan meningkatkan kepuasan pengguna, jika pengguna merasa puas dengan aplikasi yang diimplementasikan maka bisa dijelaskan bahwa aplikasi sistem informasi tersebut berhasil mendukung pencapaian harapan pengguna.

Dengan demikian maka, peneliti dapat menyimpulkan bahwa Ho ditolak dan Ha diterima. Artinya ada hubungan signifikan yang kuat dan searah antara kualitas layanan terhadap kepuasan pengguna sistem informasi manajemen rumah sakit di RSIA Srikandi Jember.

\section{Kesimpulan}

Kesimpulan yang didapat berdasarkan hasil pembahasan bahwa terdapat pengaruh signifikan yang sedang dan searah antara kualitas sistem terhadap kepuasan pengguna dalam implementasi kesuksesan SIARS di RSIA Srikandi IBI Jember 
dengan hasil nilai signifikansi atau Sig. (2-tailed) sebesar 0,000 dan angka koefisien korelasi sebesar 0,519 . Terdapat pengaruh signifikan yang sedang dan searah antara kualitas informasi terhadap kepuasan pengguna dalam implementasi kesuksesan SIARS di RSIA Srikandi IBI Jember dengan hasil nilai signifikansi atau Sig. (2-tailed) sebesar 0,001 angka koefisien korelasi sebesar 0,425.Terdapat pengaruh signifikan yang kuat dan searah antara kualitas layanan terhadap kepuasan pengguna dalam implementasi kesuksesan SIARS di RSIA Srikandi IBI Jember dengan hasil nilai signifikansi atau Sig. (2-tailed) sebesar 0,000 dan angka koefisien korelasi sebesar 0,780. Diharapkan penelitian selanjutnya bisa menggunakan analisis jalur (path analisis) untuk dapat menguji model keseluruhan dan parameter parameter individual.

\section{Ucapan Terima Kasih}

Terimakah kepada Direktur RSIA Srikandi IBI Jember yang telah memberikan ijin melakukan penelitian ini.

\section{Daftar Pustaka}

Budiastuti, S., 2015. Evaluasi penerapan sistem informasi manajemen rumah sakit dengan Model Delone and Mclean di RSUD DR. Haryoto Lumajang. Skripsi. Politeknik Negeri Jember. Jember.

Budiyanto., 2009. Evaluasi kesuksesan sistem informasi dengan pendekatan Model Delone dan Mclean (studi kasus implementasi billing system Di RSUD Kabupaten Sragen). Tesis. Universitas XI Maret Surakarta. Surakarta.

DeLone, W.H., McLean, E.R., 2003. The DeLone and McLean Model of information systems success: a ten-year update journal of management information systems. Journal of Management Information Systems. 19(4): 9-30.
Hartono, J., 2005. Analisis dan Desain Sistem Informasi. Pendekaan Struktur Teori dan Praktik Aplikasi Bisnis. Andi Offset. Yogyakarta

Livari, J. 2005. An empirical test of the model of information system success. The DATA BASE for Advances in Information System. Vol. 36(2): $8-27$.

Notoatmodjo, S., 2005. Metodologi Penelitian Kesehatan. Cetakan Ke 2. Jakarta

Permenkes., 2010. Peraturan Menteri Kesehatan Republik Indonesia Nomor 340 Tahun 2010 Tentang Klasifikasi Rumah Sakit. Kementerian Kesehatan RI. Jakarta.

Petter, S., DeLone, W., and McLean, E., 2008. Measuring information systems success: Models, dimensions, measures, and interrelationships. European Journal of Information Systems, 17(3): 236-263.

Putra, D.S.H., dan H. Prasetyo. 2015. Metodologi Penelitian Kesehatan Untuk Mahasiswa Kesehatan. Cetakan Ke 1. Graha Ilmu.Yogyakarta.

Putra, D.S.H dan M. Siswanto. 2016. Pengaruh kualitas sistem, kualitas informasi dan kualitas layanan terhadap kepuasan pengguna sistem informasi manajemen rumah sakit daerah kalisat kabupaten jember. Jurnal Ilmiah Inovasi, 16(2): $1-4$.

Sugiyono., 2010. Statistika Untuk Penelitian. Cetakan Ke 3. Alfabeta. Bandung.

Sugiyono., 2012. Metode Penelitian Kualitatif Kuantitatif dan R\&D. Cetakan Ke 14. Alfabeta. Bandung.

Wahyuni, T., 2011. Uji Empiris model Delone dan Mclean terhadap kesuksesan sistem informasi manajemen daerah (SIMDA). Jurnal BPPK 2: 424.

Salim, M.I., 2014. Analisis kesuksesan sistem informasi perpustakaan senayan dengan pendekatan model Delone dan Mclean Di SMK Muhammadiyah 3 Yogyakarta. Skripsi. Universitas Negeri Yogyakarta. Yogyakarta. 